\title{
SARS-CoV-2 as a future cause of dementia. Is anosmia as "benign" as we think?
}

\author{
SARS-CoV-2 Como causa futura de demencia. ¿Es la anosmia tan "benigna" como \\ pensamos?
}

\author{
Paola Guraieb-Chahín* \\ Neurological Center, ABC Medical Center, Mexico City, Mexico
}

Humans can perceive an immense variety of odors and odor perception greatly contributes to the generation of memories. The prevalence of olfactory impairment in the general population is approximately 3.8$5.8 \%$, which rises up to $13.9 \%$ in individuals older than 65 years ${ }^{1}$. Sensory and central processing impairment in the components of olfaction are observed in numerous neurodegenerative conditions ${ }^{2}$. These include Alzheimer's disease, vascular dementia, Parkinson's disease, and frontotemporal dementia. At present, we do not fully understand the mechanisms underlying such associations. What has been recognized is that hyposmia and anosmia are associated with a faster rate of cognitive decline compared to normal olfaction and that impaired olfaction is related to smaller hippocampus, entorhinal, fusiform, and middle temporal cortices volumes'.

Multiple cross-sectional studies have demonstrated a high incidence of hyposmia and anosmia among COVID-19 patients. Hyposmia has been reported in $20 \%{ }^{3}$ and olfactory dysfunction in up to $85 \%$ of COVID- 19 patients ${ }^{4}$. Furthermore, olfactory dysfunction preceded the development of other COVID-19 symptoms in $12 \%$ of patients and persisted once other symptoms resolved in $63 \%$ of patients ${ }^{4}$. While some of these patients recover olfactory function months after their infection, some patients experience only partial recovery. The fact that olfactory dysfunction in the form of anosmia or hyposmia can occur in isolation in COVID-19 patients suggests that there might be involvement of the olfactory nerve $^{5}$. This is supported by fact that the nasal epithelium is covered by the angiotensin-converting enzyme type 2 receptor. However, the long-term implications of anosmia are currently unknown.

Regardless of the underlying pathology, reduced olfaction is common in COVID-19 patients, where the most intriguing are those who do not regain olfactory function. This abnormality may lead to retrograde degeneration of neurons connected to the hippocampus with unforeseen consequences for patients. Consequently, this potential association merits further investigation. Recognizing patients with olfactory impairment after COVID-19 and following their cognitive status might help us understand if there is a link between olfactory impairment and cognitive decline in these patients. I think a screening during consultation post-COVID patients with basic cognitive tests could help us begin to understand if really cognitive
Correspondence:

*Paola Guraieb-Chahín

E-mail: paola.guraieb@gmail.com
Available online: 17-03-2021

Date of reception: 07-11-2020

Date of acceptance: 23-12-2020

DOI: 10.24875/RMN.20000113
Rev Mex Neuroci. 2021;22(2):40-41

www.revmexneurociencia.com (http://creativecommons.org/licenses/by-nc-nd/4.0/). 
decline is something that we will see in these patients, particularly those that had or persist with changes in olfaction.

\section{References}

1. Dintica CS, Marseglia A, Rizzuto D, Wang R, Seubert J, Arfanakis $\mathrm{K}$, et al. Impaired olfaction is associated with cognitive decline and neurodegeneration in the brain. Neruology. 2019;92:1-10.
2. Alves J, Petrosan A, Magalhaes R. Olfactory dysfuntion in dementia. World J Clin Cases. 2014;2:661-7.

3. Bénézit $F$, Le Turnier $P$, Declerck $C$, Paillé $C$, Revest $M$, Dubée $V$, et al. Utility of hyposmia and hypogeusia for the diagnosis of COVID-19. Lancet. 2020;20:1014-5.

4. Lechien JR, Chiesa-Estomba CM, De Siati DR, Horoi M, Le Bon SD, Rodriguez A, et al. Olfactory and gustatory dysfunctions as a clinical presentation of mild-to-moderate forms of the coronavirus disease (COVID-19): a multicenter European study. Eur Arch Otorhinolaryngol. 2020;277:2251-61.

5. Ellul MA, Benjamin L, Singh B, Lant S, Michael BD, Easton A, et al. Neurological associations of COVID 19. Lancet Neurol. 2020;19:767-83. 